\title{
Prawnomiędzynarodowa ochrona lasów - wybrane aspekty
}

\author{
Agata Kosieradzka-Federczyk \\ Instytut Nauk Prawnych, Uniwersytet Kardynała Stefana Wyszyńskiego w Warszawie \\ ul. Wóycickiego 1/3, 01-938 Warszawa \\ a.federczyk@uksw.edu.pl
}

\section{Streszczenie}

Problematyka dotycząca ochrony lasów w prawie międzynarodowym jest rozproszona w kilku regulacjach dotyczących różnych aspektów ochrony środowiska. Istniejący stan pokazuje, że akty te wprowadzają przede wszystkim instrumenty ochrony zasadniczego celu konwencji, natomiast ochrona lasów jest traktowana akcesoryjnie. Dotyczy to zarówno konwencji o różnorodności biologicznej, jak również ramowej konwencji narodów zjednoczonych w sprawie zmian klimatu. W tej sytuacji, chociaż ochrona lasów stanowi zagadnienie należące do problemów globalnych, nie znajduje ono prawnomiędzynarodowej ochrony, która gwarantowałaby zrównoważone użytkowanie kompleksów leśnych, a przez to bezpieczne realizowanie funkcji pełnionych przez las.

\section{Słowa kluczowe}

ochrona lasów, prawo międzynarodowe, różnorodność biologiczna, zmiany klimatu, ochrona drewna tropikalnego

\section{Wprowadzenie}

Problematyka ochrony lasów jest stale obecna w ramach dyskusji prowadzonych na międzynarodowych forach. Na przestrzeni dziesiątek lat zmieniało się podejście związane z ochroną lasów. Do funkcjonujących równolegle odmiennych poglądów o potrzebie ochrony lasów - ze względu na postrzegania go, jako fundamentu dla różnorodności biologicznej oraz podejścia polegającego na wykorzystaniu gospodarczym lasów, dołączyło trzecie, dotyczące roli, jaką lasy pełnią w działaniach przeciwko zmianom klimatu. Ze względu na złożone funkcje, jakie pełni las w gospodarce, ochrony różnorodności biologicznej, dla społeczeństwa, stanowi on przedmiot zainteresowania różnych grup interesów, co wyraża się również w bogactwie opracowań naukowych, które stanowią punkt wyjścia do niniejszego artykułu.

W literaturze szczegółowo opisano m.in. funkcje, jakie las pełni. Ze względu na przedmiot niniejszego artykułu - wystarczające będzie przywołanie podstawowych funkcji ekologicznych, wśród których wymienia się trzy zasadnicze:

1. zapewnienie środowiska życia dla gatunków fauny i flory,

2. pochłanianie części $\mathrm{CO}_{2}$, zmniejszające jego koncentrację w atmosferze, przyczyniając się do stabilizacji zmian klimatu,

3. przyczynianie się do utrzymania i wzmocnienia jakości warunków życia na ziemi, przez co tworzą warunki życia dla ludzi (Sands 2003: 546). 
Nadmierne wykorzystywanie posiadanych zasobów naturalnych stanowi jedno z zagrożeń dla realizacji zrównoważonego rozwoju. Wiek XXI to okres charakteryzujący się wzrostem zagrożeń o pochodzeniu antropocentrycznym, często o wymiarze światowym (Kaniewska et al. 2016: 215). Owa presja antropocentryczna dotyczy również wykorzystania posiadanych zasobów leśnych, co warunkuje prawidłowość procesów o charakterze globalnym. Jak zwraca uwagę J. Ciechanowicz-McLean, zasadniczą kwestią we wdrażaniu zrównoważonego rozwoju pozostaje suwerenność państwa w dysponowaniu zasobami naturalnymi, co dotyczy też zasobów leśnych i ograniczenie jej na rzecz wspólnego dobra, jakim ma być czyste środowisko (Ciechanowicz-McLean 2007: 531).

Celem artykułu jest zwrócenie uwagi na wybrane zagadnienia dotyczące obecnego stanu ochrony lasów w prawie międzynarodowym. Zostaną one przedstawione w odniesieniu do trzech tematów: pierwszy to regulacje dotyczące ochrony lasów z perspektywy różnorodności biologicznej; drugi to ochrona lasów w działaniach podejmowanych ze względu na zmiany klimatu; regulacje związane z międzynarodowym handlem drewnem tropikalnym. Wybrane zagadnienia nie wyczerpują całości problematyki dotyczącej ochrony lasów w prawie międzynarodowym, ale pozwalają na przybliżenie stanowiska formułowanego w odniesieniu do zasadniczych kwestii dotyczących lasów.

\section{Okoliczności zainteresowania społeczności międzynarodowej ochroną lasów}

Początki zainteresowania ochroną lasów w wymiarze międzynarodowym są identyfikowane z różnymi zdarzeniami. Jako jedno z nich wskazuje się utworzenie FAO, a w jej strukturach departamentu zajmującego się lasami w 1945 r. Przygotowywane od 1946 r., z niewielkimi przerwami, raporty odnośnie stanu lasów na świecie (the Global Forest Resources Assessments), tworzą obraz zmian, jakie zachodziły w monitorowanym okresie, stanowią one jednocześnie kompleksowe źródło danych wykorzystywanych na potrzeby analiz naukowych. Dopiero jednak w latach 8o-tych, wraz z wycinką znaczących powierzchni lasów tropikalnych, ochrona lasów uzyskała status globalnego problemu. Od samego początku w dyskusjach międzynarodowych zarysował się wyraźny podział stanowisk pomiędzy państwami rozwijającymi się, których powierzchnia jest pokryta w znacznym stopniu lasami (głównie tropikalnymi), a przez to zainteresowanymi pozyskiwaniem drewna jako cennego surowca, który jednocześnie stanowił wsparcie dla rozwoju narodowych gospodarek, a państwami, które ze względu na położenie geograficzne takich lasów nie posiadały, lecz domagały się zapewnienia ochrony przez państwa takie zasoby posiadające.

Wśród powstałych wówczas opracowań wykazujących bezpośredni związek pomiędzy zmniejszającą się powierzchnią lasów tropikalnych oraz wymieraniem gatunków, na uwagę zasługuje jeden z podstawowych dokumentów w obszarze międzynarodowej ochrony środowiska, raport „Nasza Wspólna Przyszłość", przygotowany przez Komisję Brundlandt w 1987 r. Wpływ, jaki raport miał na odbywającą się w pięć lat później konferencję w Rio de Janeiro pt. Szczyt Ziemi, przeniósł na trwałe problematykę ochrony lasów, w szczególności lasów tropikalnych, do zagadnień międzynarodowych.

W ramach niespełna trzyletnich prac przygotowawczych poprzedzających konferencję w Rio, została wysunięta propozycja przygotowania ogólnej konwencji dedykowanej lasom. Zgłosiły ją, m.in. kraje G7, traktujące lasy tropikalne jako dziedzictwo światowe. Spotkała się ona z silnym sprzeciwem ze strony krajów $\mathrm{G}_{77}$, postrzegających lasy przede wszystkim przez pryzmat mającej już wówczas trwałą podstawę w międzynarodowej polityce - zasady suwerenności państwa nad posiadanymi zasobami naturalnymi, a zatem również w kontekście ich zarządzania. Stanowisko krajów rozwijających się zostało wsparte oczekiwaniami dotyczącymi współfinansowania ochrony lasów. 
Wobec tak rozbieżnych stanowisk i oczekiwań, przygotowanie wiążących regulacji międzynarodowych okazało się wykraczające poza możliwości dyplomacji. Podczas prac poprzedzających konferencję w Rio de Janeiro w 1992 r. został przyjęty jedynie dokument pt. Niewiążce prawnie oficjalne stanowisko $z 1992$ r. dotyczace zasad dla globalnego porozumienia $w$ sprawie zagospodarowania, ochrony i zrównoważonego rozwoju wszystkich typów lasów.

Pomimo iż podczas Szczytu Ziemi w Rio de Janeiro nie doszło do opracowania i przyjęcia wiążącej prawnie umowy dedykowanej wyłącznie ochronie lasów, temat ochrony lasów zyskał nowe podstawy prawne w otwartych podczas konferencji do podpisu Konwencji o różnorodności biologicznej oraz Ramowej Konwencji Narodów Zjednoczonych o zmianach klimatu, jak również przyjętego Niewiażacego prawnie oficjalnego stanowiska (...).

\section{Ochrona lasów jako aspekt ochrony różnorodności biologicznej}

Głównym celem otwartej do podpisu podczas konferencji w Rio de Janeiro konwencji o bioróżnorodności, było promowanie ochrony i zrównoważonego użytkowania światowych zasobów różnorodności biologicznej. Konwencja zawiera regulacje dotyczące ochrony różnorodności biologicznej, zrównoważonego wykorzystania różnorodności oraz sprawiedliwego podziału korzyści wynikających z wykorzystania zasobów genetycznych. W przyjętym rozumieniu różnorodności biologicznej podkreślono zarówno zróżnicowanie wszystkich żywych organizmów pochodzących z ekosystemów lądowych, morskich i innych wodnych ekosystemów oraz jak również do zespołów ekologicznych, których są one częścią.

Szacuje się, że ok 70\% występujących na lądzie gatunków roślin i zwierząt żyje w ekosystemach leśnych. Z prowadzonych dokumentacji wynika również, że ok. 30\% przypadków wyginięcia gatunków została spowodowana zniszczeniem ich siedlisk (Adler 2000: 766). Jest to jedna z podstawowych przyczyn wymierania gatunków, obok wprowadzania obcych gatunków inwazyjnych.

Szczególną rolę w zakresie utrzymania bioróżnorodności biologicznej mają lasy tropikalne. Chociaż szacunkowo obejmują tylko 6\% lądowej powierzchni ziemi, stanowią siedlisko dla blisko połowy światowych zasobów bioróżnorodności (Lal Panjabi 1993: 196). Pomimo, iż przywoływane w literaturze dane dotyczące zarówno powierzchni lasów tropikalnych jak i liczby gatunków w nich zamieszkujących znacząco różnią się, nie ulega wątpliwości, że pełnią one istotną funkcję w zachowaniu różnorodności biologicznej. Powoduje to, że związek tej konwencji z ochroną lasów pozostaje oczywisty. Utrata ekosystemów leśnych stwarza bezpośrednie zagrożenie dla zachowania różnorodności biologicznej. Podstawowy sposób ochrony roślin i zwierząt przedstawiony w konwencji stanowi ochronę w ich naturalnych siedliskach (in situ), co również w tym kontekście tworzy istotny punkt zainteresowania ochroną lasu.

Już podczas pierwszego spotkania Stron Konwencji o różnorodności biologicznej w 1994 r. zauważono zasadność powołania Międzyrządowego Panelu ds. Lasów (Intergovernmental Panel on Forests, IPF), który miał ściśle współpracować $\mathrm{z}$ organami Konwencji w wybranych obszarach priorytetowych. Na kolejnych spotkaniach ustalano szczegóły dotyczące przyjęcia programu dotyczącego lasów. W szczególności podkreślano konieczność prowadzenie badań naukowych dotyczących różnorodności biologicznej w lasach, poprzez ustalenie kryteriów, wskaźników różnorodności biologicznej, jak również analizy sposobów, w jakich działalność człowieka w szczególności w obszarze zarządzania lasem, wpływa na tą różnorodność oraz w jaki sposób można wpływ negatywny minimalizować albo kompensować (COP 3 Decision III/12).

Początkowy program dotyczący różnorodności biologicznej w lasach został przyjęty w 1998 r. Wzywał on państwa, organizacje międzynarodowe i regionalne i inne instytucje do podjęcia współpracy w celu 
realizowania zadań wyszczególnionych $\mathrm{w}$ programie.

W cztery lata później - 2002 r., został przyjęty kolejny program - ujmujący tę problematykę szerzej oraz wskazujący działania, jakie powinny zostać podjęte. Nastąpiło przejście z etapu prowadzenia badań do podejmowania konkretnych działań. Program koncentrował się na trzech zasadniczych obszarach:

1. zachowanie i zrównoważone wykorzystanie różnorodności biologicznej w lasach i sprawiedliwego podziału zysków powstających w wyniku ich użytkowania;

2. instytucjonalne i społeczno-ekonomiczne uwarunkowania;

3. budowanie wiedzy o różnorodności biologicznej w lasach.

Wzmocniono także stronę naukową programu, poprzez powołanie grupy ekspertów (Ad Hoc Technical Expert Group), której zadaniem było doradztwo w zakresie założeń naukowych programów i współpracy międzynarodowej w obszarze badań, przygotowywania sprawozdań zawierających dostępne dane dotyczące statusu, kierunku rozwoju oraz zagrożenia różnorodności biologicznej w lasach oraz wskazywania odpowiednich działań zaradczych.

Realizację programu wsparto współpracą z utworzonym w ramach ONZ Forum o Lasach (United Nations Forum on Forests). Zwrócono także uwagę na konieczność oceny działań podejmowanych w ramach innych konwencji dotyczących ochrony lasów, w szczególności działań w ramach Ramowej Konwencji Narodów Zjednoczonych o Zmianach Klimatu (dalej jako: konwencja klimatyczna), tak aby pozostawały one nie tylko spójne, ale wspierały działania podejmowane w ramach Konwencji. Ewaluacja programu dokonana w 2008 r. wykazała jego niedoskonałości w zakresie realizacji oraz wskazywała na większą potrzebę koordynacji podejmowanych działań z innymi instytucjami zaangażowanymi w ochronę lasów (Web-01).
W ramach Konwencji dyskutowana jest problematyka dotycząca nielegalnej wycinki drzew oraz handlu tak pozyskanym drewnem. Na forum poruszane są również problemy zmian klimatu oraz podejmowanych w ramach działań dotyczących zmniejszania powierzchni lasów i degradacji lasów, z perspektywy różnorodności biologicznej.

\section{Ochrona lasów jako aspekt polityki klimatycznej}

Drugi obszar zainteresowania społeczności międzynarodowej ochroną lasów stanowią zmiany klimatu. Podstawowym celem konwencji klimatycznej jest doprowadzenie do ustabilizowania koncentracji gazów cieplarnianych w atmosferze na poziomie, który zapobiegałby niebezpiecznej antropogenicznej ingerencji w system klimatyczny. Zawiera również liczne zasady dotyczące organizacji międzynarodowych działań, jak ta podkreślająca konieczność ochrony klimatu na rzecz obecnych i przyszłych pokoleń odpowiednio do wspólnej, ale zróżnicowanej odpowiedzialności.

Lasy stały się jednym ze stałych punktów zainteresowania polityki klimatycznej. Dzieje się tak ze względu na zdolność pochłaniania, a następnie wiązania w biomasie węgla, którego związki powodują efekt cieplarniany oraz w pewnych sytuacjach - jego uwalniania. W ramach polityki klimatycznej podejmowane są działania na rzecz utrzymania (opcja minimum) oraz zwiększania powierzchni lasów. Lasy magazynując węgiel w biomasie, zmniejszają w ten sposób ilość gazów cieplarnianych $\mathrm{w}$ atmosferze. Jednocześnie drewno stanowi surowiec naturalny, w zależności od obszaru wykorzystania, będący alternatywą zarówno dla kopalnych źródeł energii, jak również tworzyw sztucznych. Ze względu na znaczącą powierzchnię - szacuje się, że lasy pokrywają ok. 30\% powierzchni lądów, stąd też ich rola w polityce jest znacząca.

Według szacunków ekspertów z Międzyrządowego Zespołu ds. Zmian Klimatu, powołanego w 1988 r. przez Światową Organizację Meteorologiczną i Program Ochrony 
Środowiska Narodów Zjednoczonych w celu dokonania oceny wyników naukowych badań zmiany klimatu oraz określenia jej środowiskowych i społeczno-ekonomicznych konsekwencji, a także w celu sformułowania realistycznych strategii łagodzenia tej zmiany (IPCC), wycinanie lasów jest przyczyną 20\% emisji gazów cieplarnianych do atmosfery.

Z perspektywy polityki klimatycznej rolę lasów postrzega się również poprzez inne usługi, przez nie świadczone. Należy do nich wpływanie na jakość wody, zmniejszanie erozji gleby, tworzenie warunków do utrzymania (w skali mikro) produkcyjności. Zrównoważone zarządzanie lasami może wzmocnić odporność lokalnej społeczności na zmiany klimatu, dostarczając źródeł dochodu, materiałów do produkcji, a przez to tworząc lokalne podstawy rozwoju.

Jednocześnie prognozy dotyczące zmian, jakie nastąpią w wyniku ocieplania się klimatu wskazują na znaczące oddziaływanie na lasy. Jako szczególnie dotknięte zmianami klimatu identyfikuje się lasy borealne (tajga) ze względu na ocieplenie, ale równie tropikalne lasy deszczowe, ze względu na zmniejszające się opady (Zmiany klimatu 2007, Raport syntetyczny, Warszawa 2009, 52). Do istotnych zagrożeń przyczyniających się do zwiększania emisji $\mathrm{CO}_{2}$ do atmosfery przez lasy w wyniku zmian klimatu, są ich pożary.

K. Rykowski wyróżnił cztery różne role, jakie charakteryzują las w kontekście zmian klimatu:

1. lasy mogą przyczyniać się do zwiększania emisji $\mathrm{CO}_{2}$ poprzez nieprawidłową gospodarkę leśną, w wyniku pożarów, zmiany wykorzystania terenu, wylesianie, itp.;

2. lasy mogą być ofiarą zmian klimatu - w sytuacji zmiany warunków klimatycznych na niekorzystne dla poszczególnych gatunków drzew rosnących dotychczas na danym terenie;

3. lasy jako beneficjenci zmian - zwiększony poziom $\mathrm{CO}_{2} \mathrm{w}$ atmosferze może stymulować wzrost biomasy;
4. lasy jako środek przeciwdziałający zmianom klimatu - poprzez pochłanianie $\mathrm{CO}_{2} \mathrm{z}$ atmosfery, jako odnawialny surowiec alternatywny w stosunku do paliw kopalnianych (Rykowski 2008: 6-5)

Protokół z Kioto odnosi się do pochłaniania $\mathrm{CO}_{2} \mathrm{w}$ drodze zalesiania nowych terenów oraz ponownego zalesiania w ramach Clean Development Mechanism (CDM) w części dotyczących aktywności Land Use, Land Use Change, and Forestry (LULUCF). Znaczenie podejmowania działań przeciwko uwalnianiu do atmosfery gromadzonego w ramach lasów węgla zostało uznane przez Porozumienie paryskie.

Obie okoliczności, tj. postrzeganie lasów jako "pochłaniaczy” dwutlenku węgla z atmosfery oraz szacowany negatywny wpływ zmian klimatu na stan lasów, doprowadziły do powstania programów wspierających finansowo działania na rzecz lasów. W V raporcie IPCC zaliczono działania polegające na zalesianiu, prowadzeniu zrównoważonej gospodarki leśnej, zmniejszaniu wylesiania - z zastrzeżeniem różnic występujących w poszczególnych regionach - za jedne z najbardziej kosztochłonnych (Web-02). Kwestie dotyczące kosztów polityki pochłaniania węgla $\mathrm{z}$ atmosfery poprzez kompleksy leśnie stały się przedmiotem licznych analiz ekonomicznych. Do ryzyk dotyczących rozwoju pochłaniania węgla przez lasy wskazuje się m.in. zróżnicowaną sytuację lokalną, w tym stosunki własnościowe, wzrost cen ziemi, ryzyka polityczne, jak również te dotyczące stanu lasu - jak zniszczenia lasu spowodowane przez insekty, czy pożary (Gren et al. 2016: 131).

W praktyce można podać wiele przykładów programów finansujących projekty dotyczące pochłaniania węgla przez lasy. W ramach konwencji klimatycznej działa m.in., powołany już w 1991 r. Globalny Fundusz Ekologiczny (GEF). Funkcjonowanie GEF organizuje wspólnie Bank Światowy, Program Narodów Zjednoczonych ds. Rozwoju oraz Program Ochrony Srodowiska Narodów Zjednoczonych. Finansuje on 
działania w ramach czterech priorytetowych obszarów: a) ochrona stratosferycznego ozonu, b) ograniczanie emisji gazów cieplarnianych; c) ochrona różnorodności biologicznej; d) ochrona wód międzynarodowych. Wobec wzmocnienia finansowania projektów rozwiązujących konkretne problemy państw rozwijających się, zdecydowano o utworzeniu Least Developed Countries Fund oraz Specjalnego Funduszu Zmian Klimatu (Pietraś 2011: 372-282).

Bank Światowy wprowadził również m.in. Forest Carbon Partnership Facility, wspierający przede wszystkim kraje rozwijające się, a zatem najbardziej dotknięte zmianami klimatu, w wykorzystaniu potencjału lasów do zmniejszenia ubóstwa, lepszej integracji zarządzania lasami w procesy gospodarcze. Shandong Ecological Afforestation Project (2010-2016) to jeden z projektów finansowanych przy współudziale Banku Światowego. W jego ramach zalesiono ok. 66,915 ha terenów górzystych oraz przybrzeżnych, zwiększając powierzchnię lasów, zmniejszając erozję gleby i wzmacniając różnorodność biologiczną (Web-o3).

Wśród inicjatyw na uwagę zasługuje również utworzony w 2007 r. Norway's International Climate and Forest Initiative, wspierający projekty mające na celu przeciwdziałać deforestacji w krajach rozwijających się o rocznej alokacji do 3 miliardów koron norweskich. W ramach Australia's International Forest Carbon Initiative wspierane są projekty mające na celu zmniejszenie emisji spowodowane deforestacją albo degradacją lasów.

\section{Handel drewnem tropikalnym}

Innym obszarem dotyczącym lasów poddanym regulacjom prawa międzynarodowego jest handel drewnem tropikalnym. W tym zakresie podpisywane są międzynarodowe umowy dotyczace drewna tropikalnego. Jak bardzo jest to kontrowersyjna kwestia może świadczyć fakt, że podpisanie pierwszej umowy poprzedziły 10-letnie negocjacje. Prowadziło je 70 państw, a umowę podpisano w 1983 r. (Rose 1987:
79), zastąpioną przez umowę 1994 r. Obecnie obowiązuje umowa z 2006 r. Pierwsza z umów powołała Międzynarodową Organizację ds. Drewna Tropikalnego (ITTO). Od momentu powstania, ITTO bierze aktywny udział, m.in. z FAO oraz innymi instytucjami działającymi w wymiarze międzynarodowym, w opracowywaniu i propagowaniu zasady zrównoważonego zarządzania lasami, poprzez określenie kryteriów i wskaźników dotyczących takiego zarządzania.

Zasadniczym celem przyjmowanych regulacji było promowanie międzynarodowego handlu drewnem pozyskiwanym z zasobów zarządzanych w sposób zrównoważony i, co równie ważne, pochodzących z legalnych źródeł. Umowy tworzą ramy dla konsultacji, międzynarodowej współpracy dotyczącej rozwoju polityki zarządzania handlem drewnem tropikalnym (ITTA, 2006).

Umowy zostały oparte o uznaną w prawie międzynarodowym, m.in. w deklaracji z Rio z 1992 r. zasadę suwerenności państwa w zarządzaniu posiadanymi zasobami naturalnymi, jak również odpowiedzialność za szkody wywołane poza granicami państwa podejmującego daną aktywność. Zakresem przedmiotowym umów objęto drewno tropikalne, czyli tropikalne drewno liściaste przeznaczone do celów przemysłowych, które rośnie lub jest produkowane w państwach zlokalizowanych pomiędzy Zwrotnikiem Raka a Zwrotnikiem Koziorożca.

Przygotowane regulacje miały wprowadzić ramy prawne dla legalnego pozyskiwania i handlu drewnem tropikalnym, które ze względu na swoje właściwości (kolor, twardość, zapach itp.), są atrakcyjne dla rynku. Dodatkowo, w celu wzmocnienia ochrony na poziomie międzynarodowym dla tych gatunków drzew, których populacja maleje, objęto je postanowieniami Konwencji CITES, co pozwolić miało na zwiększenie reglamentacji w zakresie handlu.

Skuteczność podejmowanych działań wydaje się być ograniczona. Nielegalny handel drewnem tropikalnym nie został wyeliminowany, na co wskazują dostępne publikacje opisujące wielkość problemu. Nieformalne, 
czyli kwalifikowane poza granicami prawa, pozyskanie drewna, stanowi ok. 34-40\% szacunków pozyskiwanego drewna w Gujanie, Republice Kongo, czy Ugandzie (Gan et al. 2016: 39). Wartość nielegalnie pozyskanego drewna ocenia się na około $100 \mathrm{mld}$ USD rocznie, choć szacunki w tej kwestii znacząco się różnią. Powszechnie uznaje się, że nielegalne pozyskiwanie drewna jest codziennym problemem w wielu państwach będących głównymi producentami drewna, a szczególnie w tych o słabych podstawach demokratycznych, w których dostęp do rynku jest łatwy.

\section{Zakończenie}

Chociaż zainteresowanie ochroną lasów w prawie międzynarodowym jest dostrzegane w różnych aspektach, co wyraża się m.in. w licznych aktach prawnych tworzących podstawy ochrony lasów, nie tworzą one kompleksowych podstaw do ochrony tego jakże ważnego elementu ekosystemu. Wśród czynników utrudniających wprowadzenie takiej ochrony można wymienić następujące: brak instytucji, która pełniłaby rolę koordynatora w zakresie polityki dotyczącej ochrony lasów. Taka instytucja tworzyłaby forum dla rozmów omawiających istniejące problemy dotyczące ochrony lasów i w jej ramach nastąpiłoby szukanie odpowiednich sposobów do ich rozwiązania. Kolejny to brak aktu, który kompleksowo regulowałby ochronę prawną lasów, stanowiłby miejsce dla opracowania jednej wiodącej w prawie międzynarodowym definicji lasu oraz degradacji lasu. Obecnie takie definicje są formułowane, ale jest ich kilka. Wprowadzenie jednej definicji mogłoby się przyczynić do większej efektywności prawnomiędzynarodowej ochrony lasów. $\mathrm{Na}$ mogące wyniknąć z takiego stanu problemy w związku z realizacją projektów finansowanych ze środków funduszy dotyczących zmian zwracają uwagę N. Sasaki i F. N. Putz (Sasaki et al. 2009).

Ponadto lasy są uwzględnianie w licznych konwencjach międzynarodowych, ale akcesoryjnie, tzn. jako jeden z elementów ochrony - w ramach konwencji o różnorodności biologicznej ze względu na miejsce bytowania gatunków roślin i zwierząt; w ramach konwencji klimatycznej - jako naturalne pochłaniacze i magazyny $\mathrm{CO}_{2}$. Obserwując regulacje poszczególnych konwencji oraz decyzje podejmowane na ich forach nasuwa się spostrzeżenie, że każda z konwencji ma „swój interes” w tym, aby chronić lasy. Instrumenty przez nie proponowane przede wszystkim koncentrują się na przedmiocie ochrony konwencji, a dopiero niejako akcesoryjnie na lasach. Jak pokazuje stan obecny - podejmowane działania nie są wystarczające dla zapewnienia odpowiedniego poziomu ochrony lasów.

Pytanie, na ile przygotowanie globalnej konwencji dedykowanej wyłącznie ochronie lasów mogłoby poprawić ich stan, pozostaje jedynie pytaniem teoretycznym. W literaturze można spotkać przewrotne określenie, że dotychczasowe wysiłki międzynarodowe podejmowane na rzecz ochrony lasów stanowią nieustającą klęskę $\mathrm{w}$ przygotowaniu takiej międzynarodowej konwencji dedykowanej wyłącznie lasom.

\section{Bibliografia}

Adler J. H., 200o, The Cartagena Protocol and Biological Diversity: Biosafe or Bio-Sorry?, in: The Gergetown International Environmental Law Review, Vol. 12:761.

Ciechanowicz-McLean J., 2007, Międzynarodowe prawo środowiska wobec problemów globalnych, Gdańskie Studia Prawnicze, Tom XVII, 521-531.

Gan J., Cerutti P.O., Massiero M., Pettenella, N. Andrighetto, T. Dawson, 2016, Quantifying Illegal Logging and Related Timber Trade, in: D. Kleinschmit, S. Mansourian, C. Wildburger, A. Purret (eds.) Illegal Logging and Related Timber Trade - Dimensions, Drivers, Impacts and Responses: A Global Scientific Rapid Response Assessment Report, IUFRO World Series no. 35, 37-59.

Gren I-M, Aklilu A. Z., 2016, Policy design for forest carbon sequestration: A review of the literature, Forest Policy and Economics Vol. 7o, p. 128-136.

Kaniewska M., Klimska A., 2016, The Policy of Sustainable Development in the Face of Contemporary 
Social Threats - Selected Aspects, Journal of Modern Science, Tom 3/30/2016, p. 213-234.

Lal Panjabi R.K., 1993, International Law and the Preservation of Species: An Analysis of the Convention on Biological Diversity Signed at the Rio Earth Summit in 1992, Dickinson Journal of International Law; Vol. 11:2.

Pietraś M., 2011, Międzynarodowy reżim zmian klimatu, Wydawnictwo Adam Marszałek, Toruń

Rose, C., 1987, International Tropical Timber Agreement, Environmental Conservation, Vol. 14(1), 79-80.

Rykowski K., 2008, Climate change, Forest, Forestry, Relationships, Centrum Informacyjne Lasów Państwowych, Warszawa.

Sands P., 2003, Principles of International Environmental Law, 2th ed., Cambridge University Press, Oxford.
Sasaki N., Putz F. E., 2009, Critical need for new definitions of "forest" and "forest degradation" in global climate change agreements, Conservation Letters, Vol. 2, No. 5, s. 226-232.

Web-o1 www.cbd.int/forest/background.shtml, dostęp: 20.06.2018.

Web-o2 IPCC (Intergovernmental Panel on Climate Change), 2014, Climate Change 2014: A Synthesis Report, www.ipcc.ch/pdf/assessment-report/ar5/ syr/AR5_SYR_FINAL_All_Topics.pdf, dostęp: 21.06.2018.

Web-03 www.worldbank.org/en/results/2017/07/26/ china-afforestation-project-in-shandong-improves-environment-and-farmers-incomes, dostęp: 20.06.2018.

\section{Selected aspects of forest protection in international law}

\section{Abstract}

The issues related to forest protection in international law are dispersed in several regulations regarding various aspects of environmental protection. The existing state shows that these acts primarily introduce instruments for protection of the main objective of the conventions. The forest protection is treated as an accessory aspect. This applies i.a. to the Convention on Biological Diversity and the United Nations Framework Convention on Climate Change. In this situation, although forest protection is an issue that is part of global problems, it does not find legal international protection that would guarantee sustainable use of forest complexes, and thus safe implementation of functions performed by the forest.

\section{Keywords}

forest protection, international law, biological diversity, climate change, timber protection 